\title{
On Aggregations of Proteid in the cells of Euphorbia splendens.
}

\author{
BY
}

R. E. F R Y, B.A.

With Plate XXIV.

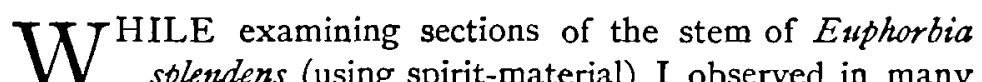
of the cells, particularly in the parenchyma immediately surrounding the vascular bundles, certain spherical bodies, which refracted light strongly and in some cases had double contours, though they were not doubly refracting.

They stained deeply with the following reagents:haematoxylin, Hanstein's violet, eosin, Hoffmann's blue. With iodine they were stained the yellowish brown colour characteristic of proteids.

They were exceedingly insoluble, not being affected by saturated $\mathrm{NaCl}$-solution, 5 per cent. potash, hydrochloric or acetic acids, or ether. These reactions suggested the presence of a coagulated proteid. This view was confirmed by the use of Millon's reagent, and the xanthoproteic test, which gave the characteristic red and deep yellow colours.

$I$ also used a test described by Loew ${ }^{1}$. It consists in precipitating the proteid by the action of a solution of potassium ferrocyanide and acetic acid, washing out these by treatment with 60 per cent. alcohol for half an hour and

1 Bot. Zeit. No. I8, May, 1884 .

[Annals of Botany, Vol. V. No. XX. November, I8gr.]

G $g$ 
adding dilute ferric chloride. The proteid is then stained blue. This test confirmed the results already obtained.

Thus the bodies were shown to consist of coagulated masses of proteid; the coagulation being probably in part the result of the action of the alcohol. In the fresh state the proteid occurs in various forms :-

(1) It may be distributed throughout the cell-contents either as a fluid or in finely divided granules. If cells containing this diffused proteid be treated with I per cent. ammonium carbonate for twenty-four hours the proteid crystallizes out.

(2) A form common in young shoots is that shown in Fig. I $a$. These long crystalloids occur either singly in bundles or united to form sphaerocrystals. They are similar to those of Galtonia candicans ${ }^{1}$ and Urtica urens $^{2}$.

(3) The long rod-like crystalloids produced artificially by the action of ammonium carbonate on (I) also occur naturally. They are shown in Fig. I $\beta$. They correspond to the forms found in Griffithsia neapolitana ${ }^{3}$.

(4) A form of crystalloid that is common in the epidermis of the leaf is the common rhombohedral crystalloid which is found in the tuber of the Potato, the berries of Solanum americanum, and in Bertholletia excelsa. Like the crystalloids of the last-named plant, those of $E u$ phorbia splendens are not doubly refracting. The crystalloids of the potato-tuber, on the contrary, are doubly refracting. Fig. $\mathrm{r} \gamma$.

Thus we see that this one species contains 4 the more remarkable forms of crystalloids that have been described as occurring elsewhere in widely different plants. But besides these there is a peculiar form. This is shown in Fig. 2, which represents a section of the stem in the fresh state mounted in water.

There are really two forms here, ( 1 ) the loose aggregations

1 Leitgeb, Mitth, aus dem Bot. Inst. zu Grax, 1886.

- Kallen, Flora, 1882, No. 5 .

- Klein, Pringsheim's Jahrb. fuir wiss. Bot., vol. XIII. 
of proteid granules shown at (c), and (2) the compact spheres (a) with strongly marked double contours; these are highly refracting. Possibly (I) is only a stage in the formation of (2). The granules showed Brownian movements and appeared to consist of globulin, as they were immediately dissolved with Io per cent. $\mathrm{NaCl}$-solution. The more aggregated spheres only became clearer in the centre, indicating possibly a globulin centre with a more insoluble shell. But the outer part also dissolved in dilute acids and was therefore probably composed of derived albumin.

Such are the forms which the proteid contained in this species assumes under various conditions. I will next discuss their distribution with a view to showing its probable function in the economy of the plant.

Distribution in the stem. This is best seen by a reference to Fig. 3, which shows a cross-section of part of the stem. The cells containing proteid occur ( 1 ) in the inner layers of the cortex just outside the bast, $(2)$ in the medullary rays $(m)$, (3) in the pith $(p)$ just within the wood.

The inner parts of the cortex contain large numbers of latex-tubes whose thick walls were stained faintly blue when treated with Loew's ferrocyanide-test, a fact which may be worth noticing by the way as it tends to support Wiesner's hypothesis of the impregnation of the cell-wall by proteid.

Although the cells surrounding the latex-tubes frequently contained proteid, there did not appear to be any such definite relation between the two as to suggest that the latextubes function as channels of distribution for the proteid. Scattered irregularly here and there are cells containing starch $(s)$, which do not, however, form a regular starchsheath. Cells containing proteid do not occur quite so constantly in the medullary rays and pith as in the inner layers of the cortex, but large quantities of proteid were frequently found in those parts.

In quite young stems proteid was frequently observed in the peripheral layers of the cortex. 


\section{Fry.-On Aggregations of Proteid in}

The cells of the growing-point and the pulvinus of young leaves are also full of proteid in a diffused form.

Distribution in the leaves. The epidermis of the petiole and lamina of the leaves frequently contains crystalloids of the cubical form.

In the mesophyll there is also a certain quantity of proteid, mostly diffuse or in irregular lumps. It is especially abundant in the cells of the palisade-parenchyma $(p)$ lying over the small fibro-vascular bundles and tracheid-bundle-endings (Fig. 4). The ordinary elongated cells of the palisade-parenchyma are here replaced by a number of small isodiametric cells with abundant cell-contents, consisting for the most part of irregularly formed masses of proteid.

From the same figure it will be seen that the parenchymatous sheath immediately surrounding the fibro-vascular bundles and tracheid-endings contains a number of spherical highly refracting bodies which at first sight seem to resemble the proteid masses of the stem; their outlines, however, are more regular and they have a faint yellow tinge. Indeed they are not unlike oil-drops. They are not doubly refracting. They were insoluble in a mixture of absolute alcohol and ether, which showed they were not of an oily nature. They were also insoluble in 5 per cent. potash, and in saturated and Io per cent. common salt solution. Dilute nitric and strong hydrochloric acid dissolved them completely. With dilute hydrochloric they became granular, less highly refracting, and less spherical.

When treated with ammonium chromate they gave no colour, showing the absence of tannin. Nor did they stain with corallin-soda, alkanet or methylene-blue. With eosin, Hoffmann's blue and Hanstein's reagent they stained deeply. With iodine they gave a deep yellow colour.

Such a behaviour towards reagents would lead one to suppose that they might be of a proteid nature, but all attempts to confirm this by positive methods failed. With Millon's reagent they gave a dull brown, with the xanthoproteic test I sometimes thought I obtained a faint yellow, but it was 
exceedingly difficult to apply, as they were dissolved in any but very weak nitric acid. With Loew's ferrocyanide-test I sometimes obtained a faint blue, very different to the deep clear blue given by the proteid masses of the stem. Perhaps the best hypothesis is to consider them as bodies very closely allied to proteid, but not answering to all the tests for it. One might perhaps compare with them mucin, which gives the characteristic proteid-reaction with the xanthoproteic test, but not with any other. Moreover since it is probable that nitrogenous food-material travels from one part of the plant to another in the form of glycines, we may provisionally regard these bodies as intermediate between the true proteids which constitute the nitrogenous reserve material, and the glycines which diffuse from cell to cell.

This view is supported by the fact that they disappear in a starving leaf.

The question naturally arises, What is the value of these proteid masses in the economy of the plant? With a view to answering this I made several observations. The very nature of the substance makes it probable that they are of importance to the plant as reserve material, and all my observations tended to support this view. I took some quite small cuttings from a plant of Euphorbia splendens and grew them with a strong bottom heat, so that they might form roots rapidly. The plants were then cut in half longitudinally and a thin slice treated with hot Millon's reagent. The distribution of proteid could then be observed macroscopically by the distribution of the red colour. The base of the stem was much redder than the apex, owing to the quantity of proteid required there for the growing roots: whereas under normal conditions the apex, where cell-division is going on, is more plentifully supplied than any other part of the stem.

I then applied a macroscopic proteid-test to the leaves. They were treated thus:-decolourized with alcohol, the cuticle carefully removed with strong and hot hydrochloric acid, and Loew's ferrocyanide-test applied. This treatment was applied to two similar leaves of two similar cuttings, 
418 Fry.-On Aggregations of Proteid, \&ec.

one of which had been kept in the dark for some days, the other in the light. As was to be expected, the etiolated leaf had used up much of its reserve proteid.

I next investigated the effect of light on the formation of proteid by imitating exactly Sachs' macroscopic starch-test, except that I substituted Loew's ferrocyanide-test for treatment with iodine. In no case did I find that light had any .effect on the quantity of proteid formed.

These observations then tend to show that the proteid is used as reserve nitrogenous material, answering to starch among carbohydrates. It is noteworthy that the distribution in the stem of the cells containing proteid is similar to that of the irregular starch-sheath, cells containing proteid alternating with cells containing starch. In all physiological respects these proteid-containing cells resemble the 'Eiweissschläuche' of the Cruciferae described by Heinricher ${ }^{1}$, as also in many respects in their distribution.

I may mention that. I examined many species of the Euphorbiaceae and many latex-containing plants of other families, belonging to the genera Manihot, Hoya, Hevea, Oxypetalum, Ficus, Sapium, Pharmacosycea, without finding any such aggregation of reserve proteids.

I ought to add that Euphorbia Bojeri, by some considered as a variety of $E$. splendens, is exactly similar to it as regards its accumulations of proteid.

In conclusion I must thank Professor Vines and $\mathrm{Mr}$. Gardiner for their helpful suggestions and advice in this investigation.

1 E. Heinricher, Eiweissechläuche d. Craciferen, Mitth. ans dem Bot. Inst. za Graz, I 886 . 

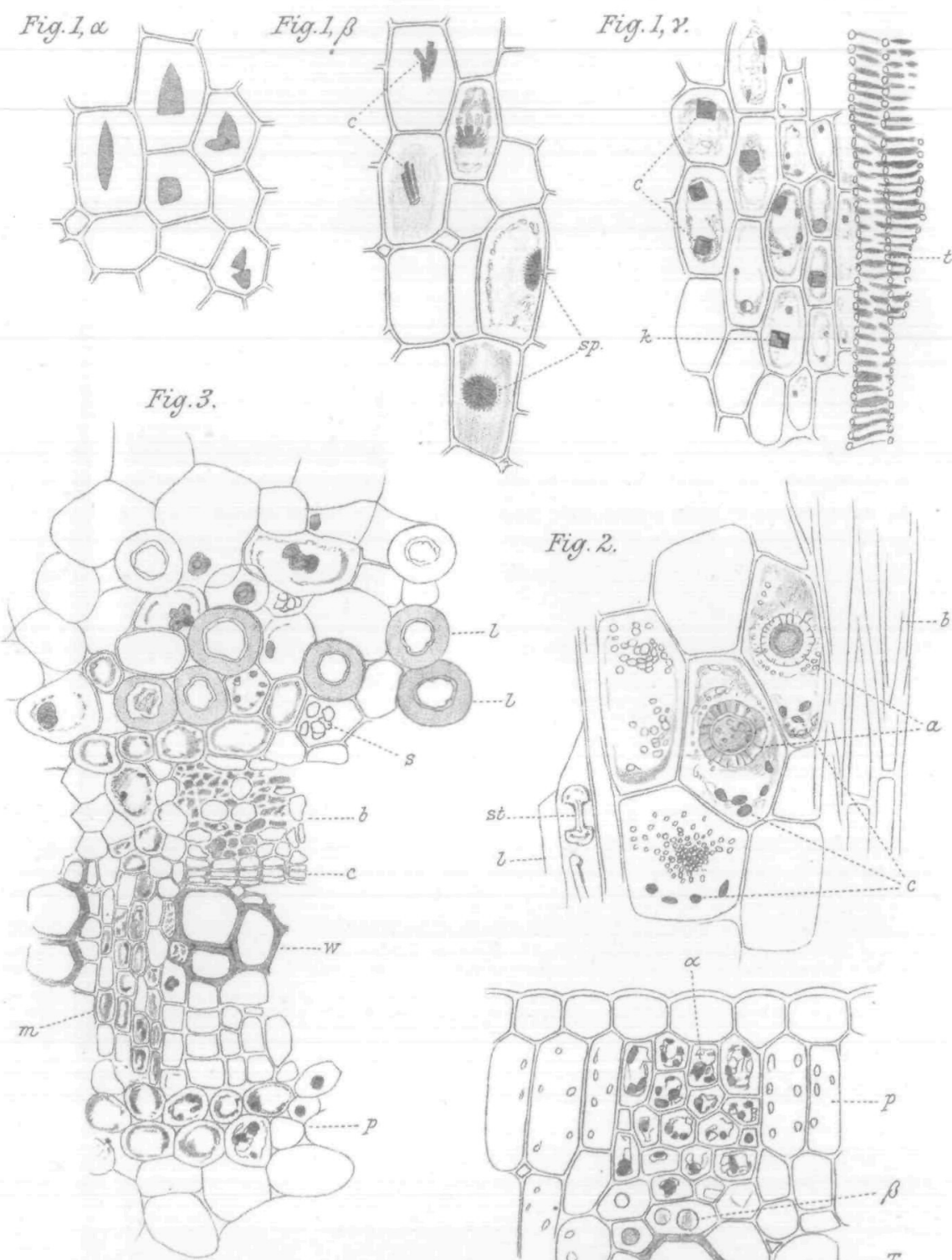

Fig. 4.

Fry del.

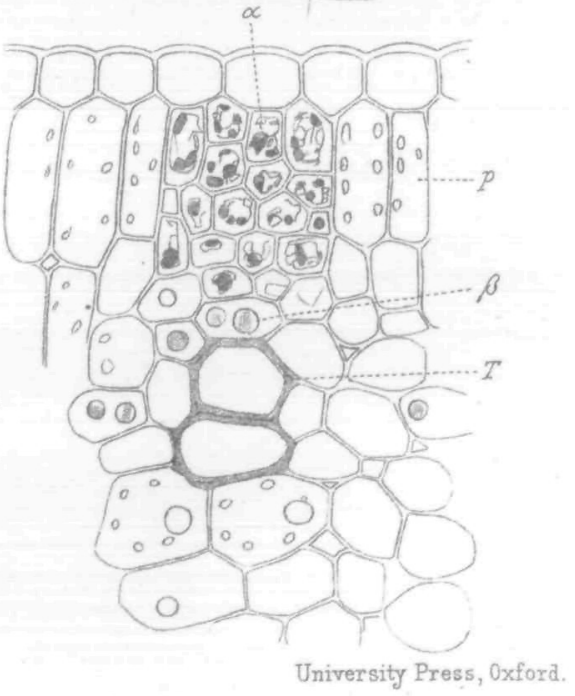

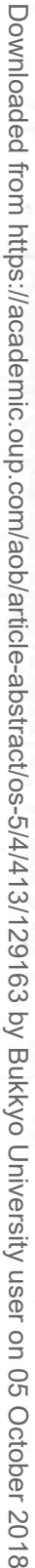

University Press, 0xford.

FRY, - ON PROTEID IN EUPHORBIA SPLENDENS. 